\title{
Erosive spondylopathy
}

\author{
C. COURTOIS, ${ }^{1}$ G. H. FAllet, ${ }^{1}$ T. L. VisChER, ${ }^{1}$ AND P. WETTSTEIN ${ }^{2}$ \\ From the ${ }^{1}$ Department of Medicine, Division of Rheumatology, and the ${ }^{2}$ Department of Radiology, University \\ Hospital, Geneva, Switzerland
}

SUMMARY Seven patients with chronic dorsolumbar pain, stiffness and some restriction of spinal movements are described. Multiple lesions of the vertebral bodies were present. The lesions occurred at various levels and all had similar radiological characteristics, often returning to normal after several years. Vertebral changes of this type may be seen in patients with ankylosing spondylitis but for a variety of cogent reasons presented in this report our patients did not readily fall into this diagnostic group. The aetiology of these vertebral lesions is unknown but available evidence indicates that they should not be attributed to an infectious or neoplastic process.

Lesions of the vertebral bodies having an erosive radiological appearance are well known in ankylosing spondylitis and have been designated by many authors as erosive or destructive spondylitides or spondylodiscitides. ${ }^{1-22}$ Although they are frequently considered as late manifestations, ${ }^{3} 67111319$ they can occur during the early years of this rheumatic disease. ${ }^{913} 161823$ In addition, their radiomorphological aspects have been classified into different stages by Jacqueline, ${ }^{7}$ Cawley et al., ${ }^{13}$ Bartunkova et al., ${ }^{15}$ and Dihlmann and Delling. ${ }^{23}$ Other, rather different, isolated vertebral lesions have been attributed to osteoarthrosis. ${ }^{24-26}$

During the last 7 years we have observed 7 patients with the type of erosive lesions seen in ankylosing spondylitis in the absence of most of the commoner clinical and radiological features of this disease. The features of these patients suggest that they do

Accepted for publication 30 August 1979

Correspondence to Professor G. H. Fallet, Division of Rheumatology, Hôpital Beau-Séjour, CH-1211 Genève 4, Switzerland. not have real ankylosing spondylitis but rather a distinct entity. These vertebral lesions could be a particular expression of a rheumatic spondylitis, which would not necessarily belong to another classical rheumatic syndrome.

\section{Patients and methods}

A total of 7 patients were studied -4 women and 3 men. Their average age was $39 \cdot 5$ years (range 22 to 54). All had moderate back pain, mostly localised to the lumbar segment, sometimes with unilateral or bilateral sciatic pain oscillating from one side to the other. In 2 cases there was in addition dorsal discomfort (Table 1). One patient (case 1) had marked morning stiffness of the spine; this was present but moderate in the other 6 . The duration of these symptoms varied between 5 and 15 years in 6 cases (average $9 \cdot 5$ years). In case 3 they started only 7 months prior to examination.

On clinical examination (Table 1) slight to moderate dorsal or low back pain could be elicited

Table 1 Age, sex, and reasons for medical consultation; clinical findings and radiological appearance of sacroiliac joints

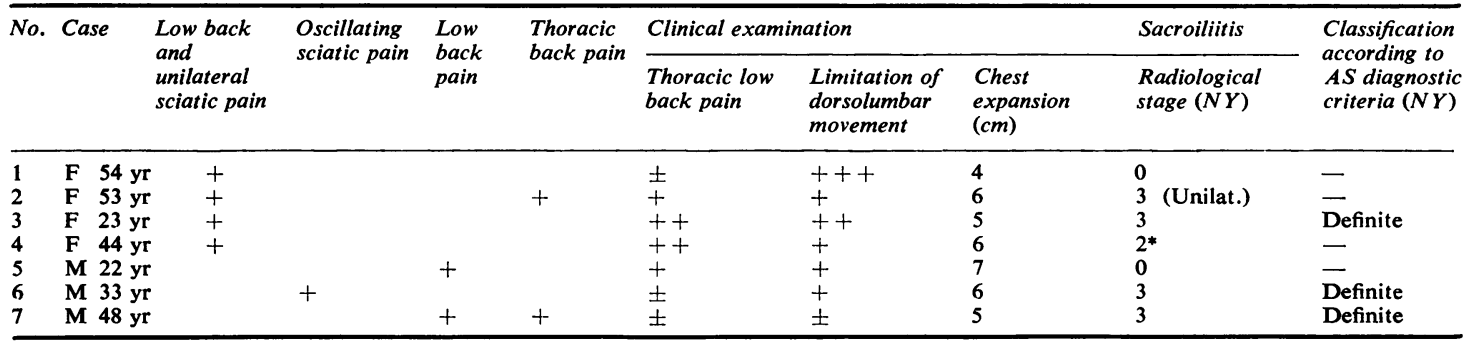

*Tomograms were interpreted as grade 3 changes. 
by transverse local pressure of the spine or by active movements of the trunk. In only 1 patient (case 1) was there marked limitation of all spinal movements. In the others the mobility of the spine was slightly to moderately restricted in all 3 planes. In 6 patients the chest expansion was normal. In case 1 it was restricted, but not below $2.5 \mathrm{~cm}$. One patient suffered from psoriasis (case 3 ); none had Reiter's syndrome, Crohn's disease, or ulcerative colitis, and none had peripheral joint lesions.

The erythrocyte sedimentation rate (Westergren) was moderately elevated in all 4 women and normal in the 3 men (Table 2). The white blood count ranged between 5.8 and $12.5 \times 10^{9} / 1$ (average $\left.8.0 \times 10^{9} / 1\right)$ ). The latex fixation test was negative in 6 patients, slightly positive $(1: 40)$ in 1 (case 3 ). The Waaler-Rose test was negative in all patients. Intradermal reaction to $2 \mathrm{U}$ of tuberculin was negative in 4 patients, strongly positive in 1 (case 1 ), and not tested in 2 (cases 5 and 6). Brucella and salmonella agglutination tests were negative in 5 cases; they were not performed in 2 (cases 1 and 6). HLA B27 antigen was present in 1 patient only (case 6) (Table 2).

A punch biopsy including bone and disc was performed in 3 patients (cases 1, 3, and 4). In case 1 the histological examination showed fibrocartilaginous tissue with nonspecific scar remodelling. In case 3 no histological examination could be made, and in case 4 the structure of the trabecular and cortical bone was normal. In all 3 cases culture of the biopsied material remained sterile for pyogens and acid-fast organisms.

\section{Results}

The sacroiliac joints were investigated by routine radiographs and by antero-posterior tomograms (Tables 1 and 2). The interpretation of standard radiographs was made according to the grading of

Table 3 Types of vertebral lesions (according to Cawley et al. ${ }^{13}$ )

\begin{tabular}{|c|c|c|c|c|}
\hline No. & Type a & Type b & Types $c$ and $d$ & Type e \\
\hline 1 & & L5 & $\overline{\mathrm{L} 3}, \quad \frac{\mathrm{L} 4}{\mathrm{L4}, \mathrm{L4}}$ & \\
\hline 2 & L5-S1 & $\overline{\mathrm{L} 3}, \underline{\mathrm{L} 5}$ & & $\begin{array}{l}\text { T8. } \mathrm{T} 8-\mathrm{T} 9 \\
\overline{\mathrm{L}}, \underline{\mathrm{L} 5}\end{array}$ \\
\hline 3 & & $\overline{L 2}(\rightarrow e)$ & $\overline{13}$ & $\overline{L 2}$ \\
\hline $\begin{array}{l}4 \\
5\end{array}$ & & $\underline{L 4}$ & $\overline{\mathrm{L1}}, \frac{\mathrm{L} 2}{\mathrm{~L} 2},{ }_{\mathrm{L} 2}^{\mathrm{L} 3}, \frac{\mathrm{L} 4}{\mathrm{~L} 3}$ & \\
\hline 6 & & $\underline{\mathrm{L} 2}$ & $\begin{array}{l}\overline{\mathrm{T} 12}, \overline{\mathrm{L} 1}, \overline{\mathrm{L} 2}, \underline{\mathrm{L3}} \\
\overline{\mathrm{L} 2}, \underline{\mathrm{L} 3}\end{array}$ & \\
\hline 7 & T11-T12 & & $\frac{\mathrm{L} 2, \overline{\mathrm{L} 3}}{\overline{\mathrm{L}}}$ & T12-L1 \\
\hline
\end{tabular}

$\underline{L 1}=$ one lesion at the upper rim of $\mathrm{L} 1 . \overline{\mathrm{L3}}=$ one lesion at the lower rim of L3. $\frac{L 4}{L 4, L 4}=$ one lesion at the upper rim of $L 4$ and two lesions at the lower rim of $\mathrm{L} 4$.

Table $2 H L A B 27$ typing in relation to the number of vertebral lesions; presence of syndesmophytes and concomitant involvement of the sacroiliac joints

\begin{tabular}{|c|c|c|c|c|c|c|c|}
\hline No. & Sex & $\begin{array}{l}\text { Number of } \\
\text { vertebral } \\
\text { lesions }\end{array}$ & $\begin{array}{l}\text { Syndesmo- } \\
\text { phytosis }\end{array}$ & Sacroiliitis & $\begin{array}{l}\text { Classification according } \\
\text { to AS diagnostic } \\
\text { criteria (NY) }\end{array}$ & $\begin{array}{l}\text { ESR (Westergren) } \\
(\mathrm{mm} / \mathrm{h})\end{array}$ & $H L A B 27$ \\
\hline $\begin{array}{l}1 \\
2 \\
3 \\
4 \\
5 \\
6 \\
7\end{array}$ & $\begin{array}{l}\text { Female } \\
\text { Female } \\
\text { Female } \\
\text { Female } \\
\text { Male } \\
\text { Male } \\
\text { Male }\end{array}$ & $\begin{array}{l}5 \\
9 \\
3 \\
7 \\
5 \\
3 \\
7\end{array}$ & $\begin{array}{l}0 \\
\text { Isolated } \\
0 \\
0 \\
0 \\
0 \\
\text { Isolated }\end{array}$ & $\begin{array}{l}\text { Absent } \\
\text { Unilat. } \\
\text { Bilat. } \\
\text { Bilat. } \\
\text { Absent } \\
\text { Bilat. } \\
\text { Bilat. }\end{array}$ & $\begin{array}{l}\overline{-} \\
\overline{\text { Definite }} \\
\overline{-} \\
\overline{\text { Definite }} \\
\text { Definite }\end{array}$ & $\begin{array}{l}22 \\
40 \\
29 \\
20 \\
3 \\
7 \\
4\end{array}$ & $\begin{array}{l}0 \\
0 \\
0 \\
0 \\
0 \\
+ \\
0\end{array}$ \\
\hline
\end{tabular}

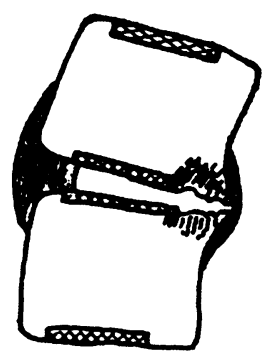

a
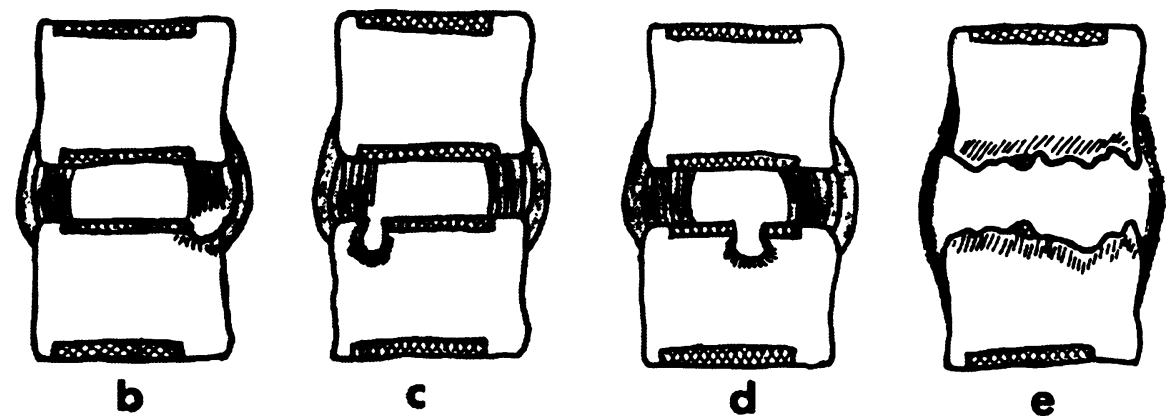

e

Fig. 1 Types of destructive lesions as seen in lateral view, anterior margin to right. $x x x=$ cartilage plate, $/ / /=$ osteosclerosis (after Cawley et al..$^{13}$ ). 
Table 4 Number and location of vertebral lesions

\begin{tabular}{llll}
\hline No. & Thoracic & Lumbar & Sacral \\
\hline 1 & 0 & 5 & 0 \\
2 & 3 & 5 & 1 \\
3 & 0 & 3 & 0 \\
4 & 0 & 7 & 0 \\
5 & 1 & 4 & 0 \\
6 & 0 & 3 & 0 \\
7 & 3 & 4 & 0 \\
Total & 7 & 31 & 1 \\
\hline
\end{tabular}

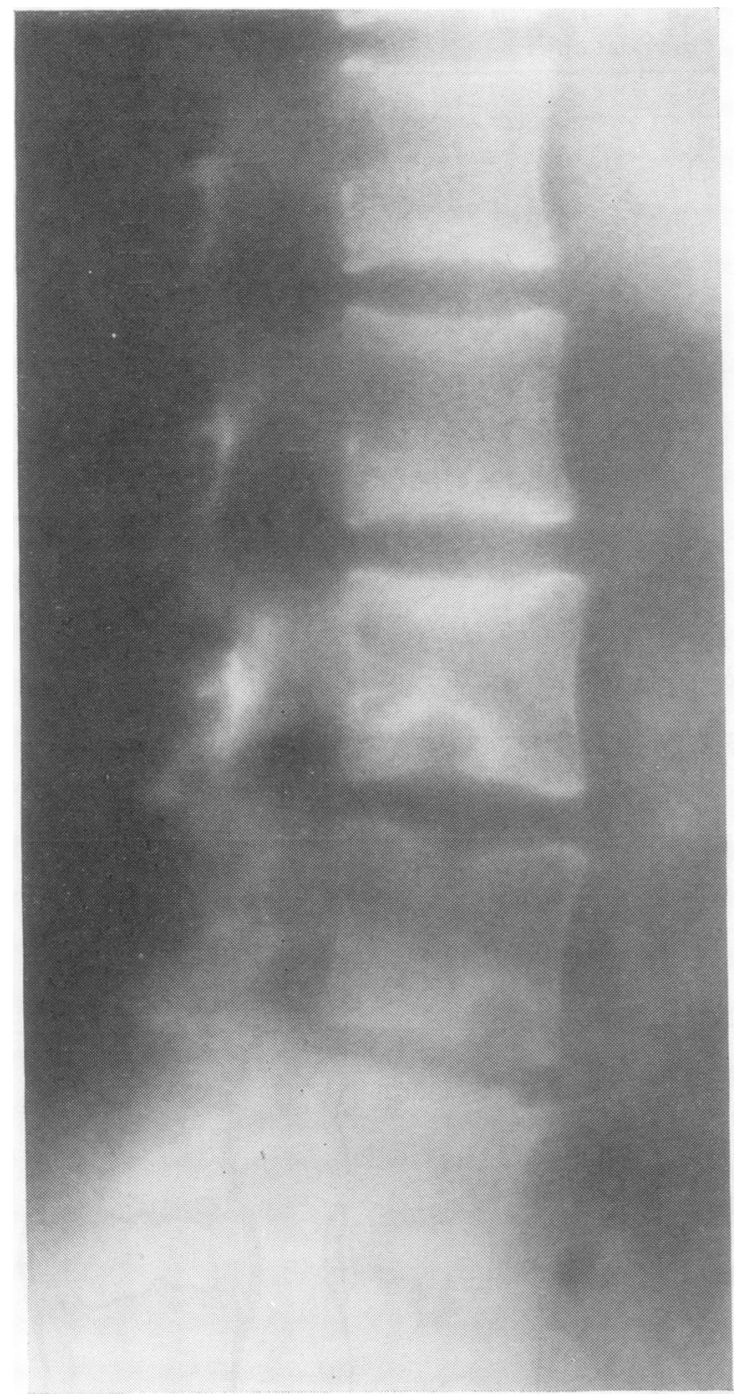

Fig. 2 Case 1, September 1972. Lateral tomogram showing erosive lesions of $L 3$ and L4 and of the superior margin of L5, with zones of sclerosis in the vertebral bone surrounding the defects. Narrowing of the $L 4 / 5$ disc. the New York diagnostic criteria for ankylosing spondylitis. ${ }^{27}$ The vertebral lesions were analysed on standard radiographs and on tomograms, and described in accordance with the classification of Cawley et al. ${ }^{13}$ In the classification (Fig. 1) vertebral lesions are differentiated according to their localisation in the vertebral endplate.

Multiple lesions with an erosive appearance were observed in all cases ( 3 to 9 lesions per patient). These were localised at different levels involving mainly the lumbar segment (Figs 2-6). More rarely, they were found in the thoracic and sacral regions (Tables 3 and 4). They had the following radiological characteristics:

Areas of apparent erosion were present in the vertebral end-plates (Figs 2-7). They were almost always focal but at times involved the end-plates

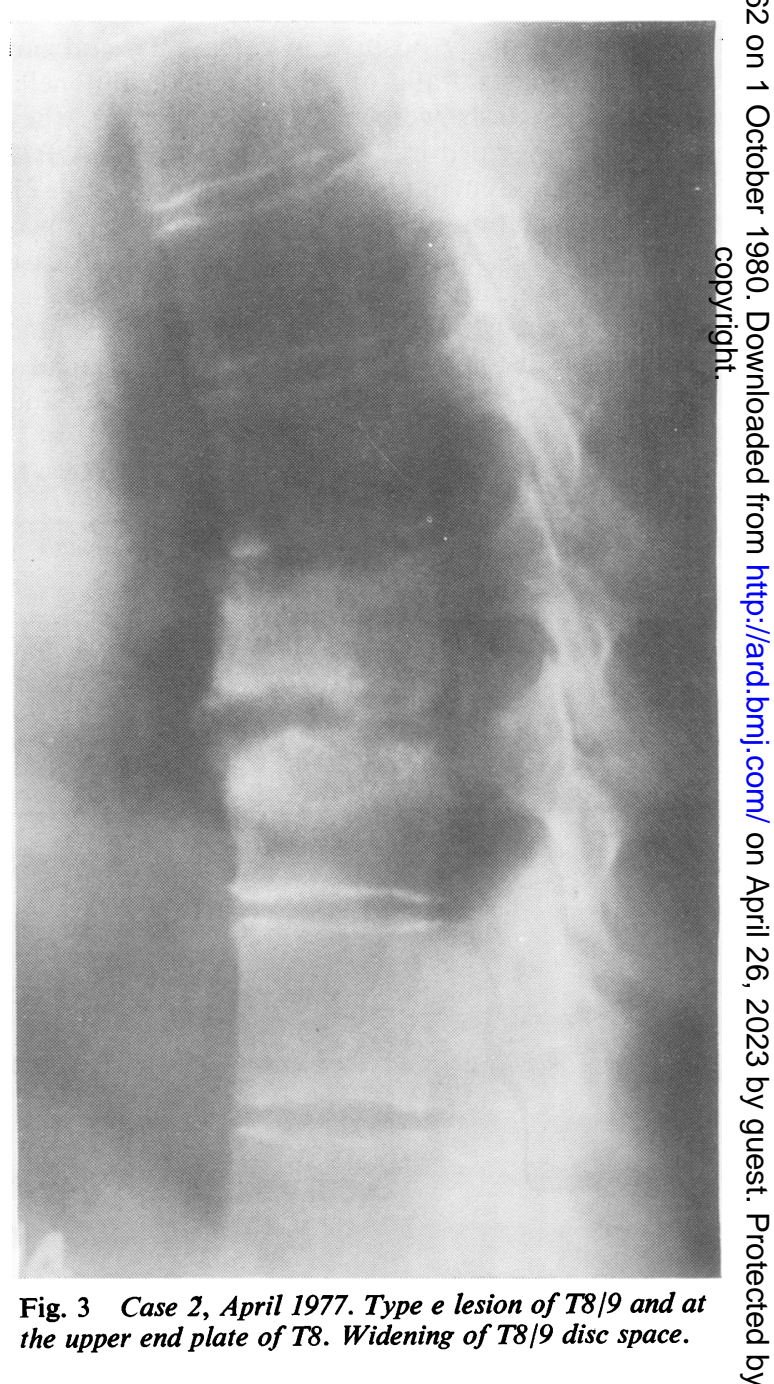




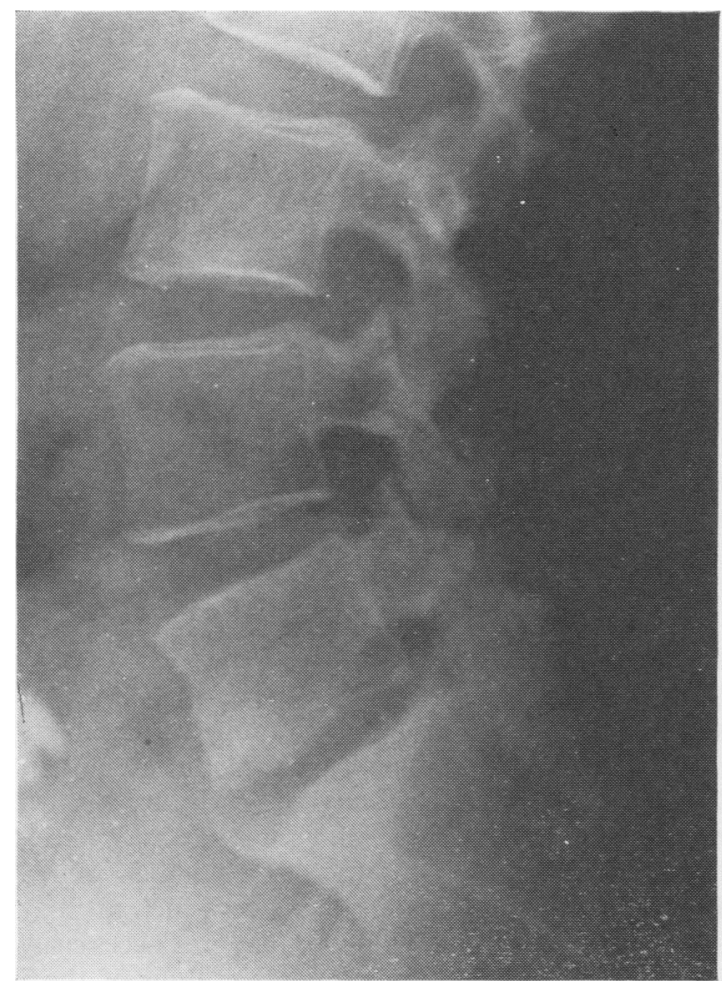

Fig. 4 Case 2, March 1975. Lateral view showing a type a lesion of L5/S1 with reactive bone sclerosis and an incomplete syndesmophyte.

diffusely (Figs. 2, 3, 5, and 7). The lesions were frequently surrounded by an expanding zone of bone sclerosis which could spread to involve most or even all of the vertebral body (Figs. 2, 3, 5, and 6).

The adjacent end plates, whether above or below, frequently remained intact (Fig. 5).

The intervertebral spaces appeared to remain unaffected or only slightly narrowed (Figs. 5 and 6). However, at times they were even enlarged (Figs. 3 and 5).

Syndesmophytes were rare. Two of the 7 patients had syndesmophytes, but these were isolated and different from those seen in the classical bamboo spine (Figs. 4 and 5). On the other hand, neither reactional osteophytosis nor intervertebral synostosis as seen in osteoarthrosis were observed.

The radiological course of the erosive-appearing lesions was of interest. They showed an impressive dynamic activity both in their formation and in their regression (Figs. 4, 5, and 7). Many developed in sites previously shown to be radiologically intact (Figs. 4, 5, and 7). In some patients the lesions were already pre-existent. Each lesion appeared to have its own individual evolution which was not uniform.

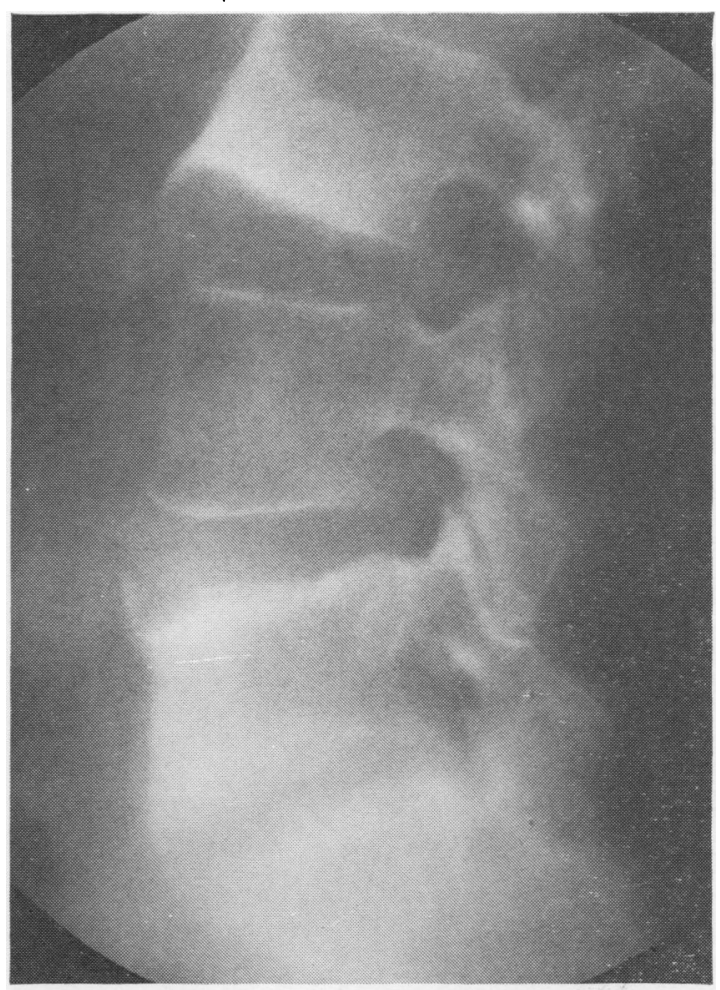

Fig. 5 Case 2, June 1977. Tomogram of the lumbar spine showing the progression of the type a lesion of $L 5 / S 1$. New lesion of type $b$ at the lower anterior rim of L3 and at the upper anterior rim of L5 with incomplete syndesmophytes. No narrowing of the disc spaces. Note the integrity of the L4 endplates.

The following possible sequences were observed: (1) Condensation, repair, or sclerosis. (2) Recovery with complete restitution of the vertebral integrity. (3) Appearance of atypical isolated syndesmophytes. (4) Persistence of vertebral lesions.

Since patients frequently complained of minor back pain which did not cause them to seek medical advice, it was difficult to determine the exact delay between the first clinical manifestations and the radiological discovery of the vertebral lesions.

\section{Discussion}

Lesions similar to those present in the 7 patients reviewed are occasionally seen in patients with classical ankylosing spondylitis. Under these circumstances two hypotheses have been advanced to explain their pathogenesis, one suggesting an inflammatory process and the other a degenerative reaction. 
Most authors agree that there is an inflammatory basis for the anterior spondylitis described by Romanus and Yden, ${ }^{2}$ which can be the initial stage of syndesmophyte production. ${ }^{2} 619$ 28-30 Some have concluded that the spondylodiscitis of ankylosing spondylitis is secondary to an inflammatory

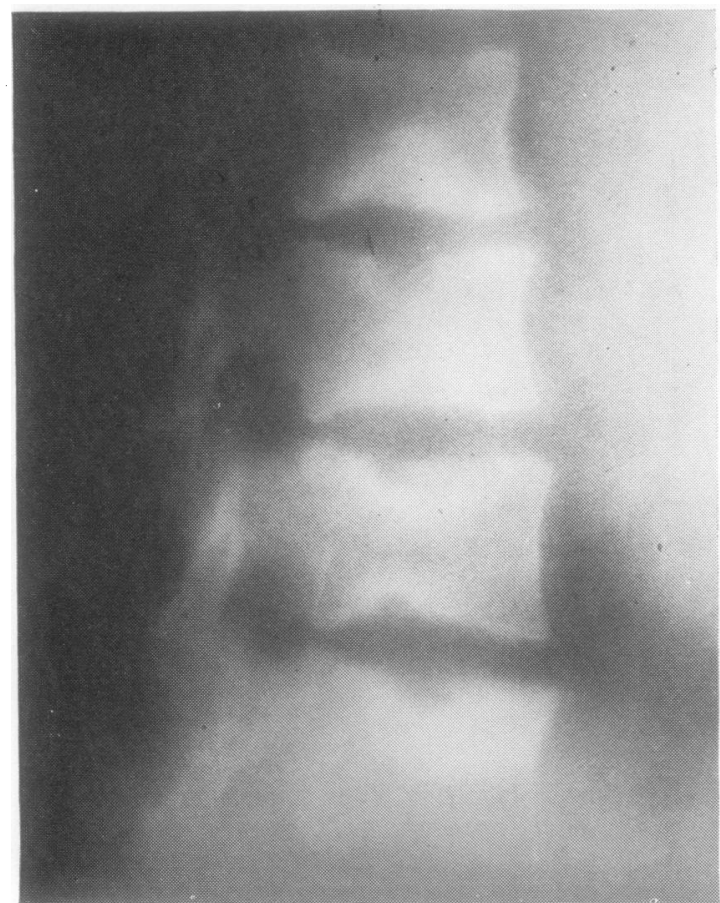

Fig. 6 Case 4, September 1972. Tomogram of the lumbar spine showing type $c$ and $d$ lesions from $L 1$ to L4 with surrounding bony sclerosis. Little alteration of the disc spaces. No syndesmophytes are seen.
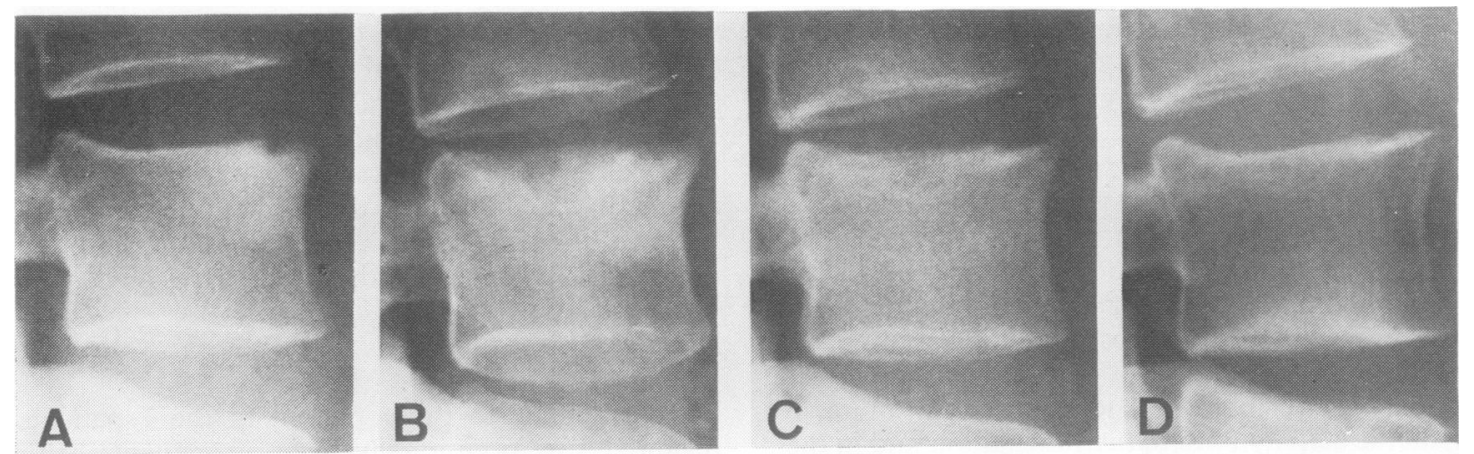

Fig. 7 Case 4. Lateral view showing the progression of a type b lesion of the upper anterior rim of L4. A. February 1971: type b lesion of L4. The lower end plate of L3 is not altered. The L3/4 disc is not narrowed. B. September 1972: type $c$ lesion at the lower end-plate of L3 and type $d$ lesion at the upper end-plate of L4. Increased bony sclerosis surrounding the type $b$ defect which already involved the upper end plate of L4. C. June 1974: regression of the erosive lesions and the bony sclerosis of L4. D. February 1979: complete healing of L4.

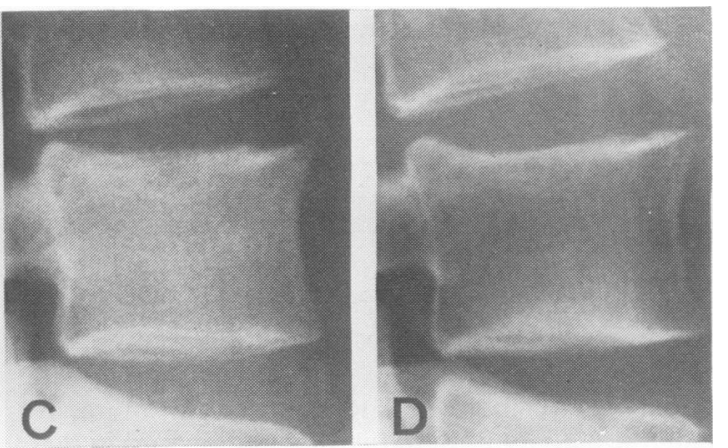

extension of the anterior spondylitis to the discs and end plates. ${ }^{1-4} 202830$ More recent studies have suggested that these are degenerative changes secondary to repeated mechanical trauma which cause localised microfractures of osteoporotic bone and penetration of the disc into the vertebral body. 10111319213132 For the latter group of authors there does not exist a transition from the anterior spondylitis to the spondylodiscitis. Dihlmann and Delling ${ }^{23}$ in a recent study classified these destructive vertebral lesions seen during the course of ankylosing spondylitis into 3 types: one inflammatory, a second non-inflammatory (which can be distinguished radiologically, histologically, and by the time of its appearance), and a third type that these authors qualify as 'ambivalent', i.e., showing both pes of change.

In the present investigation all the 7 patients in suffered from an erosive-appearing spondyathy localised at multiple levels of the spine and owing a course frequently leading to complete radiological recovery. The clinical picture resembles that of ankylosing spondylitis with back-ache, morning stiffness, and mild or marked restriction of movement of the dorsolumbar spine. suggest that this spondylopathy may not necessarily be related to ankylosing spondylitis. Four of the 7 patients were female. All the patients had normal chest expansion, 2 had completely normal sacroiliac radiographs (Table 1), one 5 years, the other 7 years after the onset of the low back pain. Only 1 patient was HLA B27 positive (Table 2). Finally, in no case was there an evolution of the classical ossification of the spinal ligaments seen in ankylosing spondylitis. 
Based on the New York diagnostic criteria proposed by Bennett and Wood ${ }^{27}$ the diagnosis of definite ankylosing spondylitis could be made in 3 patients, but only because they had sacroiliitis (Table 1). The 2 subjects with completely normal sacroiliac joints (cases 1 and 5) nevertheless had the same clinical and radiological features as the other patients. Thus, if the present series of patients could be said to have ankylosing spondylitis, this disease would have to be present in a very atypical form. Moreover, it would be very difficult to accept this diagnosis in patients 1 and 5 , who had completely normal sacroiliac radiographs years after the beginning of their disease.

Cases resembling those here presented have been observed previously by Verhaeghe and Lebeurre ${ }^{33}$ and by De Sèze et al. ${ }^{34}$ Verhaeghe and Lebeurre ${ }^{33}$ described them under the term "chronic evolutive spondylodiscitides' and De Sèze et al. ${ }^{34}$ under 'isolated rheumatic spondylodiscitides.' We would prefer to call this condition an erosive spondylopathy and not a spondylodiscitis, since the intervertebral space appears to be preserved or only slightly altered.

The absence of significant changes in the intervertebral discs, the slow development, the tendency towards spontaneous healing of some vertebral lesions, as well as their multiplicity, make a bacterial process highly improbable. It also seems likely that the lesions here described are not of a mechanical origin and thus do not correspond to those observed by Martel $^{24}{ }^{25}$ and more recently by Lagier et al. ${ }^{26}$ The latter involve mostly one spinal level and are associated with a narrowed disc giving the radiological picture of a true 'pseudospondylodiscitis'.

The vertebral pathology present in the 7 patients of this series cannot be precisely defined. Determination of whether this is an inflammatory disease or a purely degenerative process will be possible only from very early histological observations. It is important at present, however, to avoid attributing these spinal lesions to an infectious process ${ }^{35}$ or to a tumour, ${ }^{23}$ with all the therapeutic consequences that such interpretations may involve.

We express our gratitude to Dr M. I. D. Cawley, consultant rheumatologist, Southampton General Hospital, for permitting us to reproduce Fig. 1 of this article.

\section{References}

1 Baggenstoss A H, Bickel W H, Ward L E. Rheumatoid granulomatous nodules as destructive lesions of vertebrae. J Bone Joint Surg 1952; 34: A 601-9.

${ }^{2}$ Romanus R, Yden S. Destructive and ossifying spondylitic changes in rheumatoid ankylosing spondylitis (pelvospondylitis ossificans). Acta Orthop Scand 1952; 22: 88-99.

3 Wholey M H, Pugh D G, Bickel W H. Localized destructive lesions in rheumatoid spondylitis. Radiology $1960 ; 74: 54-6$.
4 Lorber A, Pearson C M, Rene R M. Osteolytic vertebral lesions as a manifestation of rheumatoid arthritis and related disorders. Arthritis Rheum 1961: 4: 514-32.

5 Seaman W B, Wells J. Destructive lesions of the vertebral bodies in rheumatoid disease. Am J Roentgenol 1961; 86: 241-50.

6 Coste F, Delbarre F, Cayla J, Massias P, Beasley E. Spondylites destructives dans la spondylarthrite ankylosante. Presse Méd 1963; 71: 1013-16.

7 Jacqueline F. Destructions du rachis antérieur lombodorsal au cours de la spondylarthrite ankylosante. Rhumatologie 1965; 17: 223-38.

8 Dihlmann W. Spondylitis ankylopoetica-die Bechterewsche Krankheit. Stuttgart: Thieme 1968; 105.

${ }^{9}$ Hicklin J A. Erosive vertebral disease in ankylosing spondylitis. Ann Physical Med 1968; 9: 206-8.

10 Kanefield D G, Mullins B P, Freehafer A A, Furey J G, Horenstein S, Chamberlin W B. Destructive lesions of the spine in rheumatoid ankylosing spondylitis. $J$ Bone Joint Surg 1969; 51A, 1369-75.

11 Rivelis $M$, Freiberger $R$ H. Vertebral destruction at unfused segments in late ankylosing spondylitis. Radiology 1969; 93: 251-6.

12 Ravault P P, Lejeune E, Bouvier M. et al. Les formes atypiques de la spondylarthrite ankylosante (A propos de l'analyse de 236 observations). Rev Rhum Mal Osteoartic 1970; 73: 197-206.

13 Cawley M I D, Chalmers T M, Kellgren J H, Ball J. Destructive lesions of vertebral bodies in ankylosing spondylitis. Ann Rheum Dis 1972; 31: 345-58.

14 Pohl W, Kränzlein H G. Über blande sklerosierende Spondylitiden. ROEFO 1973; 119: 352-7.

15 Bartunkova V, Streda A, Susta A, Kralova M. Verlauf destruktiver Veränderungen bei ankylosierender Spondylitis. Z Rheumatol 1974; 33: 254-66.

16 Little H, Urowitz M B, Smythe H. A, Rosen P H. Asymptomatic spondylodiscitis. An unusual feature of ankylosing spondylitis. Arthritis Rheum 1974; 17: 487-93.

17 Seignon B, Tellart M O, Etienne J C, Robert J F, Gougeon J. Spondylodiscites de la pelvispondylite rhumatismale: lésion inflammatoire ou lésion mécanique? (A propos d' une observation). Rhumatologie 1974; 26: 251-8.

18 Doury P, Delahaye R P, Pattin S, et al. La spondylodiscite pseudo-pottique au cours de la spondylarthrite ankylosante. Ann Méd Interne (Paris) 1975; 126: 697-701.

19 Frank P, Gleeson J A. Radiology now. Destructive vertebral lesions in ankylosing spondylitis. $\mathrm{Br} J$ Radiol 1975; 48: 755-8.

20 Sutherland R I, Matheson D. Inflammatory involvement of vertebrae in ankylosing spondylitis. $J$ Rheumatol 1975; 2 : 296-302.

21 Gougeon J, Rampon S, Deshayes P, et al. Discopathies post-fracturaires et lésions vertébrales destructrices au cours de la pelvispondylite rhumatismale. Rev Rhum Mal Osteoartic 1977; 44: 17-25.

22 Modena V, Migone N, Daneo V, Carbonara A O, Di Vittorio S, Viara M. Spondylodiscitis and ankylosing spondylitis: HLA typing and nosological implications. Ann Rheum Dis 1978; 37: 510-2.

23 Dihlmann W, Delling G. Disco-vertebral destructive lesions (so-called Andersson lesions) associated with ankylosing spondylitis. Skeletal Radiol 1978; 3: 10-16.

24 Martel W, Seeger J F, Wicks J D, Washburn R L. Traumatic lesions of the discovertebral junction in the lumbar spine. Am J Roentgenol 1976; 127: 457-64.

25 Martel W. A radiologically distinctive cause of low back pain. Arthritis Rheum 1977; 20: 1014-18. 
26 Lagier R, Guelpa G, Gerster J C. Lumbar erosive intervertebral osteochondrosis. ROEFO 1979; 130: 203-9.

27 Bennett P H, Wood P H N. Population studies of the rheumatic diseases. Proceedings of the 3rd International Symposium. New York. Excerpta Medica, Amsterdam: $1966 ; 456$.

28 Engfeldt N, Romanus R, Yden S. Histological studies of pelvo-spondylitis ossificans (ankylosing spondylitis) correlated with clinical and radiological findings. Ann Rheum Dis 1954; 13: 219-28.

29 Ball J. Enthesopathy of rheumatoid and ankylosing spondylitis. Ann Rheum Dis 1971; 30: 213-23.

30 François R J. Le Rachis dans la Spondylarthrite Ankylosante. Brussels: Arscia, 1975; 156.

31 Raymond G, Gascon J, Bourgeau D, RaymondTremblay D. Manifestation vertébrale inhabituelle de

la spondylarthrite ankylosante. Union Méd Can 1972; 101 : 896-8.

32 Resnick D, Niwayama G. Intravertebral disk herniations: cartilaginous (Schmorl's) nodes. Radiology 1978; 126: 57-65.

33 Verhaeghe A, Lebeurre R. Spondylo-discites chroniques évolutives. Lille Méd 1961; 6: 1071-6.

34 Sèze de S, Hubault A, Guérin C, Guidet M, Simonin D, Strauss J. Les spondylo-discites rhumatismales isolées. A propos de deux observations. Rev Rhum Mal Osteoartic 1967; 34: 617-21.

35 Bontoux D, Saporta L, Guiraudon C, Massias P, Delbarre F. Les spondylodiscites infectieuses. Problème du diagnostic (Comparaison de $\mathbf{3 0}$ cas de mal de Pott et de 30 cas de spondylodiscite non tuberculeuse). Rev Rhum Mal Osteoartic 1969; 36: 541-9 